\title{
Estetika Gerak Tari Rejang Sakral Lanang Di Desa Mayong, Seririt, Buleleng, Bali
}

\author{
I Made Rianta ${ }^{1}$, Hendra Santosa ${ }^{2}$, I Ketut Sariada ${ }^{3}$ \\ ${ }^{1,2}$ Program Studi Penciptaan dan Pengkajian Seni (S2) \\ ${ }^{3}$ Program Studi Seni Karawitan \\ Institut Seni Indonesia Denpasar \\ ²hendrasnts@gmail.com
}

Tari Rejang Sakral Lanang di Desa Mayong, Kecamatan Seririt, Kabupaten Buleleng adalah sebuah tari sakral yang memiliki keunikan salah satunya terletak pada gerak tarinya. Memahami dan mengetahui estetika gerak dalam Tari Rejang Sakral Lanang di Desa Mayong merupakan tujuan penelitian ini. Pengumpulan data penelitian ini menggunakan teknik observasi tidak berstruktur, teknik wawancara, studi dokumentasi, dan studi kepustakaan. Berdasarkan analisis data yang dilakukan, diperoleh kesimpulan yaitu gerak Tari Rejang Sakral Lanang di Desa Mayong hanya terdiri dari empat gerakan yang selalu dipergunakan secara berulang-ulang dari awal tarian hingga akhir tarian, sehingga struktur dari tarian ini menggunakan struktur tunggal. Adapun empat gerakan tersebut meliputi: agem, nengkleng, nindak, dan nutup. Gerakan pada tarian ini memiliki estetika karena sesuai dengan pendapat dari Thomas Aquinas yang berpendapat bahwa, keindahan meliputi tiga persyaratan yaitu kesatuan, perimbangan, dan kejelasan. Kesatuan dapat dilihat dari gerak dalam tari tersebut didukung dengan tata busana, tata rias, tempat pementasan dan musik iringan tari sesuai dengan karakter tari; Keseimbangan dapat dilihat dari pengulangan gerakan dari kanan ke kiri maupun dari kiri ke kanan karena disebabkan struktur dalam tarian serta adanya keharmonisan antara desain lantai dan desain atas; Kejelasan gerak Tari Rejang Sakral Lanang dapat dilihat dari pementasannya yang menampilkan hanya empat gerakan saja yang diulang-ulang dari awal hingga akhir tarian. Gerakan yang dilakukan juga didukung oleh penari, tata busana, tata rias, dan tempat pementasan yang juga dapat dilihat kejelasannya.

Kata kunci: estetika, gerak, tari rejang sakral lanang

\section{Aesthetic Movement of Rejang Sacral Lanang Dance in Mayong Village, Seririt, Buleleng, Bali}

Rejang Sakral Lanang Dance in Mayong Village, Seririt District, Buleleng Regency is a sacred dance that has a unique one of which lies in the dance motion. Understanding and knowing the aesthetics of movement in the Rejang Sakral Lanang Dance in Mayong Village is the aim of this study. This research data collection uses unstructured observation techniques, interview techniques, documentation studies, and literature studies. Based on the data analysis, the conclusion is that the movement of Rejang Sakral Lanang Dance in Mayong Village consists of only four movements that are always used repeatedly from the beginning of the dance to the end of the dance, so that the structure of this dance uses a single structure. The four movements include: agem, nengkleng, nindak, and nutup. Movement on this dance has aesthetics because it is in accordance with the theory of Thomas Aquinas who argues that, beauty includes three requirements, namely unity, balance, and clarity. Unity can be seen from the movements in the dance supported by fashion, cosmetology, staging and dance accompaniment music in accordance with the character of the dance; Balance can be seen from the repetition of movements from right to left or from left to right because it is caused by the structure in the dance and the harmony between the floor design and the upper design; The clarity of the movements of the Rejang Sakral Lanang Dance can be seen from the performance which features only four movements that are repeated from the beginning to the end of the dance. The movements carried out are also supported by dancers, fashion, makeup, and staging venues that can also be seen clearly.

Keywords: aesthetics, movement, rejang sakral lanang dance

Proses Review : 1 - 20 Agustus 2019, Dinyatakan Lolos: 22 Agustus 2019 


\section{PENDAHULUAN}

Tari merupakan satu di antara seni-seni yang mendapat perhatian cukup besar dari masyarakat. Tari merupakan alat ekspresi dan komunikasi yang universil. "Masyarakat memerlukan sekali tari, bukan saja sebagai sarana kepuasan estetis saja, tetapi lebih dalam yaitu sebagai sarana di dalam upacara-upacara agama dan adat" (Soedarsono, 1977:02). "Tari-tari untuk upacara adat mempunyai peranan yang penting dalam kehidupan rohani masyarakat yang akibatnya juga berpengaruh pada kehidupan jasmani mereka" (Soedarsono, 1977:22). Salah satu tari yang berfungsi sebagai tari upacara yaitu Rejang.

"Tari Rejang merupakan tari yang divisualkan dengan gerak-gerak lemah gemulai, sederhana dan bernuansa meditatif dan dibawakan massal (berkelompok) oleh penari-penari putri (dengan segala umur) yang dipentaskan di halaman pura ketika berlangsungnya upacara agama (odalan)" (Dibia, 1999:10). Pernyataan tersebut didukung juga oleh Yudabakti serta Watra (2007:68) mengatakan pada intinya, "Rejang ditarikan oleh gadis-gadis suci menurut lontar Usana Bali yang menyimbolkan widyadari turun ke dunia untuk menyambut manifestasi Tuhan ketika upacara agama yang diiiringi dengah tabuh dan ada pula diiringi dengan vokal/kidung". Hal sama disampaikan oleh Bandem (1983:122) yang menyebutkan bahwa, "Rejang merupakan sebuah tari tradisional yang diungkapkan dengan rasa pengabdian kepada para leluhur dan ditampilkan melalui gerak polos (sangat sederhana). Tata busananya menggunakan pakaian adat daerah masing-masing dan di kepalanya biasanya dihiasi bunga-bunga emas".

Berdasarkan ketiga pemaparan di atas dapat diartikan bahwa Tari Rejang adalah tari upacara yang ditarikan oleh perempuan yang suci dan bersih serta didukung dengan pakaian upacara di dalamnya sehingga tarian ini dipentaskan pada saat odalan dan memiliki keterkaitan dengan upacara agama.

Salah satu Tari Rejang yang masih dilestarikan hingga saat ini adalah Tari Rejang Sakral Lanang di Desa Mayong yang memiliki keunikan dan berbeda dengan Tari Rejang yang disampaikan oleh para ahli, sehingga menjadi ciri khas dari daerahnya. Tarian ini hanya dipentaskan pada tempat dan waktu tertentu yang sangat terkait dengan upacara Dewa Yadnya di Desa Mayong, Kabupaten Buleleng. Menurut Koentjaraningrat (1995:303) mengatakan bahwa, "dewa yadnya memiliki arti upacara terutama yang berkenaan dengan upacara-upacara di pura". Tari Rejang Sakral Lanang di Desa Mayong harus dipentaskan dalam Pujawali Rejang yang dilaksanakan setiap 15 tahun sekali di Desa Mayong yang diiringi dengan gamelan Gong Kebyar Bali Utara yang berbeda dengan gamelan Gong Kebyar Bali Selatan. Tarian yang hanya dipentaskan jika ada hubungan dengan upacara agama merupakan tari upacara atau sakral.
Tari sakral dipentaskan sejalan dengan kegiatan keagamaan di Bali yang pada umumnya diatur dan dikembangkan oleh masyarakat yang memiliki adat di dalamnya. Agung (2004:08) mengatakan bahwa, adat dan agama di Bali merupakan dua hal yang sulit dipisahkan. Kesatuan agama dan adat tidak saja terlihat lekat di dalam kehidupan bermasyarakat di Bali namun juga dalam kehidupan ritual, magis dan kesenian. Masyarakat Bali memiliki bermacam-macam kesenian yang bersumber pada agama sehingga kesenian dan agama tidak bisa dipisahkan (kemanunggalan). "Berkesenian bagi orang bali adalah sarana (media) persembahan kehadapan Tuhan, sehingga berkesenian pada dasarnya memisikan ajaran Ketuhanan (Weda) yang terdiri dari kebenaran (satyam), kesucian (siwam) dan keindahan (sundaram) kepada masyarakat" (Yudabakti, 2007:33).

Berdasarkan kedua pemaparan di atas, dapat diartikan bahwa kesenian di Bali bersumber pada Agama Hindu yang dilestarikan oleh adat setempat, sehingga merupakan wujud bakti kepada Tuhan Yang Maha Esa yang pada setiap pementasannya mengandung ajaran-ajaran agama. Salah satu daerah di Bali yang memiliki kesenian yang terkait dengan upacara agama adalah Desa Mayong yang memiliki kesenian Tari Rejang Sakral Lanang di Desa Mayong yang dipentaskan setiap upacara Pujawali Rejang di Desa Mayong.

Keunikan Tari Rejang Sakral Lanang di Desa Mayong jika dibandingkan dengan Tari Rejang lainnya secara umum yaitu terdapat pada waktu pementasan, penari, dan gerak tari yang dipergunakan. Bandem (1983:122) mengatakan "pada umumnya Tari Rejang ditarikan oleh penari-penari perempuan di dalam mengikuti upacara persembahyangan". Namun berbeda halnya dengan Tari Rejang Sakral Lanang di Desa Mayong, Kecamatan Seririt, Kabupaten Buleleng yang ditarikan oleh penari laki-laki yang belum menikah atau beristri yang berumur 15 tahun karena dianggap masih suci dan bersih. Jika dilihat dari bentuknya Tari Rejang Sakral Lanang ini termasuk tari yang berbentuk kelompok besar yang ditarikan oleh 15 orang penari yang memiliki gerakan yang cukup sederhana. Gerakan pada Tari Rejang Sakral Lanang sangat berbeda dengan Rejang pada umumnya. Bandem (2005:20) mengatakan, "gerakan dalam Tari Bali harus mengikuti suatu peraturan serta norma yang meliputi wiraga (bangun tubuh dan kualitas gerak), wirama (musik atau ritme), wirasa (wibawa dan ekspresi)".

Gerakan Tari Rejang pada umumnya yang ditarikan oleh wanita memiliki gerakan yang sangat sederhana serta terdapat beberapa gerakan seperti ngukel, ambil selendang, ngembat, ngegol, agem, piles dan lain sebagainya yang diikat oleh wirama, wiraga dan wirasa. Gerakan yang ada pada Tari Rejang Sakral Lanang di Desa Mayong berbeda dengan gerakan Rejang pada umumnya yaitu gerakannya hanya terdiri dari empat gerakan yang diulang dari 
awal hingga akhir tarian yang meliputi gerakan agem, nengkleng, nindak dan nutup yang juga diikat dengan wirama, wiraga dan wirasa serta memiliki nilai estetika di dalam gerakannya.

Gerak dalam Tari Rejang Sakral Lanang walaupun hanya terdiri dari empat gerakan, namun terdapat unsur estetika di dalamnya. "Estetika adalah filsafat tentang hal yang indah, ilmu tentang keindahan dan citarasa" (Gie, 2004:12). "Menurut Thomas Aquinas, estetika dibangun dengan tiga unsur keindahan yang meliputi kesatuan, perimbangan dan kejelasan" (Gie, 2004:42). Estetika gerak dalam Tari Rejang Sakral Lanang memiliki kesatuan yang dapat dilihat dari gerak yang dibawakan oleh penari yang didukung dengan tata busana, tata rias, tempat pementasan dan musik iringan tari sehingga sesuai dengan karakter Tari Rejang Sakral Lanang di Desa Mayong; Keseimbangan dalam gerak Tari Rejang Sakral Lanang yang memiliki karakter di dalamnya dapat dilihat dari pengulangan gerakan dari kanan ke kiri maupun dari kiri ke kanan karena disebabkan struktur dalam tarian menggunakan struktur tunggal serta keseimbangan dalam gerak tari ini didukung juga dengan unsur-unsur lain yang juga memiliki keseimbangan di dalamnya, sehingga menjadi sebuah keseimbangan yang utuh; Kejelasan dalam gerak Tari Rejang Sakral Lanang salah satunya dilihat dalam pengungkapan gerak tari ketika pementasannya yang menampilkan hanya empat gerakan saja yang diulang-ulang dari awal hingga akhir tarian, sehingga hal tersebut menyebabkan estetika gerak dalam tarian ini berbeda dengan Tari Rejang pada umumnya. Kejelasan yang terdapat dalam gerakan juga didukung dengan unsur-unsur lain dalam tari, sehingga dapat mendukung karakter tarian tersebut.

Berdasarkan dari keunikan Tari Rejang Sakral Lanang di Desa Mayong, peneliti tertarik untuk menjadikan objek ini sebagai bahan penelitian dikarenakan tarian ini belum ada yang meneliti sebelumnya, sehingga peneliti tertarik untuk meneliti tarian tersebut hanya dari estetika gerak yang ada dalam tari tersebut, sehingga tarian ini dapat dilestarikan dan diharapkan menjadi inspirasi untuk penciptaan seni.

\section{METODE PENELITIAN}

Materi dalam penelitian ini adalah hanya mengetahui estetika gerak yang terdapat dalam Tari Rejang Sakral Lanang di Desa Mayong, sehingga penelitian ini hanya menjelaskan tentang estetika gerak yang termasuk ke dalam bagian dari bentuk Tari Rejang Sakral Lanang di Desa Mayong.

Penelitian estetika gerak Tari Rejang Sakral Lanang di Desa Mayong menggunakan desain penelitian deskriptif analitik yang mendeskripsikan suatu peristiwa secara apa adanya lalu menganalisisnya, sehingga menjawab persoalan yang diteliti. Menurut Ratna (2010:336) "metode deskriptif analitik adalah metode dengan cara menguraikan sekaligus menganalisis". Jenis data dalam peneli- tian ini meliputi data primer dan data sekunder. Jenis data primer berupa hasil pengamatan dan hasil wawancara dari informan mengenai Tari Rejang Sakral Lanang di Desa Mayong. Sementara jenis data sekunder berupa pengetahuan dan informasi yang diperoleh dari sumber dokumentasi berupa literatur, buku maupun jurnal terkait yang digunakan untuk memperkuat hasil analisis kajian. Sarwono (2006:225) mengatakan bahwa "jenis data primer berupa foto, rekaman pementasan, dan hasil wawancara diperoleh langsung di lapangan dengan cara dicatat melalui catatan tertulis atau direkam melalui rekaman audio. Jenis data sekunder adalah informasi yang diperoleh dari kajian dokumen".

Sumber data yang digunakan dalam penelitian ini adalah sumber data primer dan sumber data sekunder. Sumber data primer berupa pertunjukan Tari Rejang Sakral Lanang di Desa Mayong dan para informan terpilih. Moleong (2012:157) mengatakan bahwa "sumber data primer dalam penelitian kualitatif adalah fenomena dan tindakan orangorang yang diamati (observasi). Data yang telah terkumpul dicatat melalui catatan tertulis atau melalui rekaman video/audio tapes, pengambilan foto, atau film". Sumber data sekunder yang berkaitan dengan estetika gerak Tari Rejang Sakral Lanang di Desa Mayong berupa literatur, buku, dan jurnal. Moleong (2012:159) mengatakan bahwa "sumber data sekunder adalah sumber data sekunder adalah sumber data yang diperoleh secara tidak langsung dari orang lain". Teknik pengumpulan data dalam penelitian ini meliputi observasi tidak berstruktur, wawancara, studi dokumentasi, dan studi kepustakaan.

\section{ANALISIS DAN INTERPRETASI DATA}

Material tari adalah tubuh penari dengan mediumnya berupa gerak yang indah. "Tari merupakan pengungkapan ekspresi manusia dengan jiwanya dalam ritmisan keindahan gerak yang di dalamnya memiliki penyampaian-penyampaian yang ingin disampaikan. Melalui penyampaian yang dapat dimengerti, bisa mudah dipahami oleh penonton sampai kepada penyampaian yang simbolis (abstrak) yang agak sukar sekali dimengerti, tetapi tetap bisa dirasakan keindahannya" (Soedarsono, 1977:34-35). Tari Rejang Sakral Lanang di Desa Mayong memiliki gerakan yang indah dan mengandung maksud di dalamnya yang diungkapkan dengan empat gerakan di dalamnya. Menurut Hadi dalam buku Menciptakan Lewat Tari (terjemahan dari buku Creating Through Dance oleh Alma M. Hawkins) (2003:1-2), mengatakan bahwa "karya seni tari diwujudkan sebagai perasaan manusia yang berekspresi yang diolah dengan imajinasi dan diimplementasikan ke gerakan yang wantah lalu diubah bentuknya menjadi seni melalui tubuh sebagai alat yang efektif dan terampil lincah dalam bergerak. Kekuatan komunikatif yang terdapat di dalamnya merupakan esensi dari kehidupan". Kussudiardjo dalam bukunya Tentang Tari (1981:16) juga mengatakan bahwa, "seni tari adalah bergeraknya manusia melalui tubuhnya 
(anggota badan) dan menciptakan keindahan, memiliki irama dan memiliki keharmonisan jiwa. Gerak tercipta oleh manusia melalui anggota-anggota tubuh (badan) yang sudah memiliki bentuk, lalu digerakan. Gerakan yang ditampilkan dapat berdiri bersama-sama, sendiri, dan bersambungan serta memiliki irama sehingga tercipta harmonis". Berdasarkan pemaparan ketiga pendapat di atas dapat dianalisis atau dikaji sebagai berikut. Gerak tari merupakan perasaan manusia yang berekspresi, diimplementasikan ke gerakan yang wantah lalu diolah menjadi gerak yang indah, memiliki irama dan memiliki keharmonisan jiwa. Gerak tari sebagai seni mempergunakan material seni berupa anggota badan penari di dalamnya. Anggota badan tersebut dari kepala hingga kaki.

"Tari Bali memiliki jalinan gerak dan ekspresi estetis yang membutuhkan sikap dasar tubuh yang sangat berbeda dengan tari-tarian daerah lain di Indonesia dan suku bangsa lainnya di dunia" (Dibia, 2013:36). Sejalan dengan itu Bandem (2005:19-20) mengatakan bahwa, "sumber gerak tari Bali yang diangkat menjadi bentuk seni yang tinggi bersumber dari flora, fauna, berbagai gerak dari kehidupan sehari-hari, bersumber pada mudra, dan penggunaan busana”. Gerak Tari Rejang Sakral Lanang di Desa Mayong sederhana dan tidak memakai lakon di dalam pertunjukannya, tetapi memiliki estetika. Gerak pada Tari Rejang Sakral Lanang di Desa Mayong termasuk ke dalam gerak tari yang bersumber pada kehidupan sehari-hari yaitu pemujaan kepada Tuhan. Gerakan yang ditampilkan termasuk ke dalam stalisasi gerak yang mempunyai arti "merubah gerak wantah ke dalam gerak yang mengandung keindahan (stilir). Penstiliran gerak tari dan mengandung arti dalam dunia tari disebut gesture atau gerak maknawi" (Soedarsono, 1977:35).

Gerak Tari Rejang Sakral Lanang di Desa Mayong hanya terdiri dari empat gerakan saja yang gerakannya diulang-ulang dari awal tarian hingga akhir tarian, sehingga Tari Rejang Sakral Lanang ini menggunakan struktur tunggal di dalamnya. "Struktur tunggal merupakan struktur yang terdiri dari bagian-bagian meliputi awal, tengah dan akhir dalam satu rangkaian (satu kesatuan) yang bulat tanpa adanya pergantian irama musik iringan tari atau perubahan melodi” (Dibia, 2013:114). Keempat gerakan tersebut terdiri dari :

Agem

"Gerakan agem yaitu sikap pokok berdiri dalam Tari Bali. Agem dalam Tari Bali sesuai dengan watak masing-masing tokoh yaitu keras atau manis" (Bandem, 1983:5). "Agem dalam Tari Bali sangat ditentukan oleh dua hal yaitu posisi berdiri atau penempatan berat badan (kiri, kanan dan tengah), dan jenis gender tari” (Dibia, 2013:56). Agem Tari Rejang Sakral Lanang mempergunakan dua agem yaitu agem ngawan dan agem ngebot.

"Agem ngawan (kanan) adalah sikap pokok yang divisualkan dengan kaki kanan sebagai tumpuan berat badan dan kaki kiri sebagai penyangga. Dalam posisi seperti ini, posisi tubuh terkesan agak miring atau rebah ke kanan, pundak berada dalam posisi lurus, tangan kanan setinggi mata (sirang mata) dan tangan kiri setinggi dada (sirang dada)" (Dibia, 2013:56).

"Agem ngebot adalah sikap pokok yang divisualkan dengan kaki kiri sebagai tumpuan berat badan dan kaki kanan sebagai penyangga. Dalam posisi seperti ini, posisi tubuh terkesan agak miring atau rebah ke kiri, pundak berada dalam posisi lurus, tangan kiri setinggi mata (sirang mata) dan tangan kiri setinggi dada (sirang dada)" (Dibia, 2013:56).

Agem dalam Tari Rejang Sakral Lanang di Desa Mayong dilakukan dengan posisi ngaed (lutut ditekuk). "Dalam posisi ngaed, kedua telapak kaki (depan dan belakang) menapak di lantai walaupun yang menumpu berat badan tetap kaki yang di belakang" (Dibia, 2013:58).

\section{Nengkleng}

"Gerakan nengkleng yaitu gerakan kaki yang ditekuk (nengkleng) dan ayunan ke belakang maupun ke samping" (Dibia, 2013:53). Lebih lanjut Dibia mengatakan gerakan kaki meliputi dua macam yaitu gerakan kaki sebagai penyanggah tubuh dan gerakan kaki tanpa mengandung tekanan berat badan. Nengkleng termasuk ke dalam gerakan kaki sebagai penyanggah tubuh dan gerak kaki tanpa mengandung tekanan berat badan. "Nengkleng merupakan salah satu jenis gerakan agem, sebab gerakan nengkleng dilakukan di tempat dan dilakukan melalui perubahan posisi tubuh dan anggota badan, termasuk meluruskan lutut, tanpa memindahkan poros tubuh dari posisi semula" (Dibia, 2013:64). Gerakan nengkleng dalam Tari Rejang Sakral Lanang juga didukung dengan gerakan salah satu tangan di dalamnya yang digerakkan menuju ke depan dada. Dibia (2013:53) mengatakan bahwa, "gerakan tangan bersumber pada telapak tangan dan jari tangan. Perubahan posisi lengan adalah akibat dari atau untuk mendukung gerakan tangan yang bisa bersumber pada siku, pengelangan tangan dan jari tangan".

\section{Nindak Batis}

Gerakan nindak batis adalah gerakan yang dilakukan setelah gerakan nengkleng. Nindak batis merupakan gerakan melangkahkan salah satu kaki (kanan atau kiri) yang diarahkan ke depan. Nindak batis termasuk ke dalam jenis gerakan tandang yang berarti gaya berjalan meliputi semua gerak langkah yang menyebabkan terjadinya perpindahan tempat (locomotif movement) dengan kualitas gerak, tempo dan lintasan garis yang berbeda-beda. "Tandang berfungsi untuk memindahkan posisi penari di atas pentas, dari satu tempat ketempat yang lainnya, sekaligus sebagai penghubung dari sekuen-sekuen gerak yang ada dalam suatu tarian" (Dibia, 2013:64). 


\section{Nutup Batis}

Gerakan nutup batis adalah gerakan yang dilakukan setelah gerakan nindak batis. Nutup batis merupakan gerakan melangkahkan salah satu kaki (kanan atau kiri) yang diarahkan ke depan dan berada dibelakang kaki yang telah melakukan gerakan nindak batis. Gerakan nutup batis dilakukan setelah gerakan nindak batis, sehingga nutup batis termasuk ke dalam jenis gerakan tandang yang juga memiliki fungsi "untuk memindahkan posisi penari di atas pentas, dari satu tempat ketempat yang lainnya, sekaligus sebagai penghubung dari sekuen-sekuen gerak yang ada dalam suatu tarian" (Dibia, 2013:64). Gerakan nindak dan nutup batis merupakan gerakan kaki sebagai penyanggah tubuh, sebab pada gerakan tersebut kaki dihentakan ke lantai serta melangkah dengan arah dan pola ritme.

Keempat gerakan tersebut didukung dengan tangkep (ekspresi) di dalamnya. "Tangkep adalah ekspresi atau perubahan emosi yang tercermin melalui wajah. Sebagaimana halnya tangkep bisa terjadi sebagai bagian dari agem, tangkis, maupun tandang” (Dibia, 2013:65). Ekspresi wajah penari Rejang Sakral Lanang mengarah kepada ekspresi pemujaan atau tanpa beban.

Tari Rejang Sakral Lanang di Desa Mayong walaupun hanya terdiri dari empat gerakan saja, tetapi gerakan tersebut memiliki estetika di dalamnya. "Menurut Thomas Aquinas mengatakan bahwa keindahan meliputi tiga persyaratan, yaitu: keutuhan atau kesempurnaan, perimbangan atau keserasian dan kecemerlangan atau kejelasan" (Gie, 2004:42). Berikut di bawah ini hubungan estetika menurut Thomas Aquinas yang dikaitkan dengan gerak Tari Rejang Sakral Lanang di Desa Mayong.

"Keutuhan atau kesempurnaan (Integrity or perpefection) menurut Aquinas adalah penampilan karya seni haruslah memiliki kelengkapan yang terdiri dari unsur-unsur yang saling mendukung, sehingga tidak dapat terlepas" (Gie, 2004:42). Tari Rejang Sakral Lanang sebagai tari kelompok besar memiliki dua prinsip estetis. Dibia (2013:112) mengatakan bahwa "dua prinsip dari tari kelompok adalah kompak dan rampak. Kompak yang dimaksudkan setiap penari bergerak dalam waktu, tempat, ruang serta pola gerak yang sama. Rampak dimaksudkan para penari bergerak secara serempak dengan rasa serta semangat jiwa yang sama”. Kesatuan gerak dalam Tari Rejang Sakral Lanang di Desa Mayong dapat dilihat dari para penari yang menarikan tarian tersebut yang menyatukan pikiran dan hati mereka ketika membawakan gerakan dalam Tari Rejang Sakral Lanang dan didukung oleh para penabuh yang mengiringi tarian tersebut, sehingga antara gerak dalam tari dengan musik iringan tari tidak dapat dipisahkan dan memiliki kesatuan di dalamnya.

Menurut Putu Ardian Eka Putra (wawancara pada tanggal 05 Oktober 2017) yang merupakan seorang pelatih dan penari tari Rejang Sakral Lanang di Desa Mayong men-

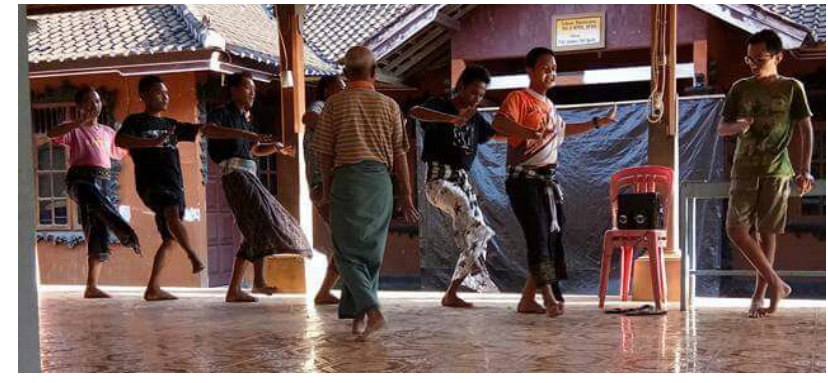

Gambar 1. Penari melakukan proses latihan di yang dilatih oleh penari senior yang pernah menarikan tarian ini

(Dok. Lita, 2017)

gatakan bahwa, pada saat latihan pertama, pelatih memberikan pemahaman mengenai tujuan tarian, gerakan serta makna dari tarian itu, kemudian pelatih memberikan gerak tidak menggunakan musik iringan melainkan menggunakan hitungan untuk manghafal dan merasakan tarian tersebut. Setelah para penari sudah dianggap hafal, barulah tarian tersebut diiringi dengan musik iringan tari Rejang Sakral Lanang yang sudah direkam terlebih dahulu.

"Ada beberapa faktor dalam tari tradisi Bali yang dapat mengungkapkan karakterisasi dari penampilan suatu peran (tokoh). Faktor-faktor tersebut adalah perbendaharaan gerak, dialog, musik pengiring, tata rias wajah dan busana tari. Faktor-faktor di atas merupakan aturan-aturan yang sudah baku" (Widjaja, 1997:82). Gerakan dalam Tari Rejang Sakral Lanang merupakan salah satu elemen dari bentuk dalam Tari Rejang Sakral Lanang yang juga didukung dengan elemen-elemen lain dalam tari meliputi musik iringan tari, tata rias, dan tata busana yang sesuai terhadap karakter dari tari, sehingga menjadi satu kesatuan yang utuh (saling terkait) dan dapat mendukung keutuhan gerak dalam Tari Rejang Sakral Lanang di Desa Mayong. "Bentuk gerak dan karakter tari putra dibedakan ke dalam dua bagian meliputi tari putra keras serta tari putra halus" (Cerita, 2009:13). Sejalan dengan pendapat tersebut, Soedarsono (1977:39) mengatakan bahwa, "gerak-gerak tari bisa dibedakan menjadi tiga berdasarkan volume geraknya yang meliputi watak kelaki-lakian dapat dilihat dari volume gerak besar atau terbuka, watak kewanitaan dapat dilihat dari volume gerak kecil atau tertutup, dan watak kelaki-lakian yang halus dapat dilihat dari volume gerak sedang”. Gerak tari pada Tari Rejang Sakral Lanang di Desa Mayong mengarah kepada gerak dengan volume sedang yang memberi kesan halus. Tari Rejang Sakral Lanang di Desa Mayong jika dilihat dari gendernya termasuk ke dalam tari putra halus, sebab karakter dari Tari Rejang Sakral Lanang di Desa Mayong dapat dilihat dari warna tata busana. Dibia (2013:85) mengatakan bahwa, "karakter tokoh yang digambarkan dalam sebuah tari sering kali ditunjukkan dengan warna dasar busana terutama saput dan atau kain". Warna dalam tata busana Tari Rejang Sakral Lanang di Desa Mayong dominan terdiri dari warna kuning dan putih yang dapat memberikan kesan halus dalam tarian, sehingga dapat memberikan kesatuan antara gerak dan tata busana. Lebih lanjut gerakan yang dilakukan oleh penari 


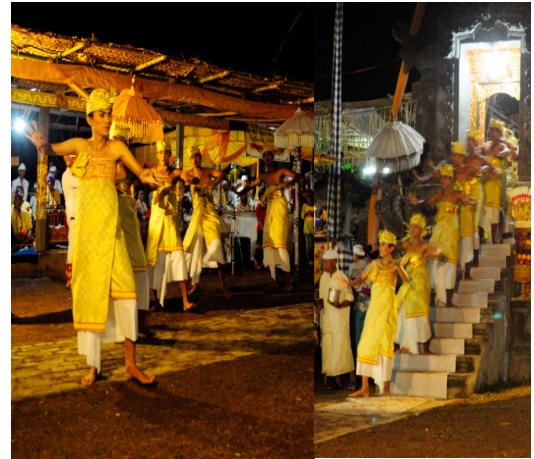

Gambar 2. Gerakan agem ngawan dan agem ngebot dalam Tari Rejang Sakral Lanang di Desa Mayong

(Dok. Kurnia, 2017)

Rejang Sakral Lanang yang didukung dengan pakaian adat madya sebagai tata busananya, sehingga tata busana tidak menjadi kendala di dalam melakukan gerakan yang terdapat pada Tari Rejang Sakral Lanang di Desa Mayong. Tata busana dalam tarian ini juga dipengaruhi dengan tata rias yang mempergunakan riasan natural yang juga memberikan kesan halus di dalamnya, sehingga, kesatuan antara gerak dan tata rias dapat dilihat dari gerakan yang dilakukan oleh penari Rejang Sakral Lanang merupakan gerakan tari putra halus, sehingga tata rias yang dipergunakan adalah tata rias natural sebagai pendukungnya. Kesatuan antara gerak dan musik iringan tari dapat dilihat dari ritme yang dibawakan oleh penabuh di dalam memainkan gamelan Gong Kebyar Bali Utara (gamelan tua) sebagai musik iringan tari yang sesuai dengan gerakan yang dibawakan oleh penari Rejang Sakral Lanang di Desa Mayong, sehingga antara gerak dan musik iringan menjadi satu kesatuan. Soedarsono (1977:47) mengatakan bahwa, "ritme adalah elemen dasar dari musik yang terdapat pula dalam sebuah tarian. Dengan aksen yang diulang-ulang secara teratur dari degupan musik disebut ritme, sehingga musik adalah partner dari tari".

Keempat gerakan yang terdapat dalam Tari Rejang Sakral Lanang di Desa Mayong dilakukan secara berulang-ulang dari awal hingga akhir tarian ketika pementasan Tari Rejang Sakral Lanang, sehingga terdapat suatu keutuhan di dalamnya. Menurut Jro Made Antara (wawancara pada tanggal 27 Oktober 2017), sebagai Ketua Gong Desa Mayong mengatakan bahwa, Tari Rejang Sakral Lanang di Desa Mayong merupakan "kesenangan" dari Sesuhunan di Desa Mayong, dan bukan Tari Baris. Tari Rejang Sakral Lanang dan Tari Rejang Sakral Istri merupakan tarian kesenangan dari Sesuhunan, sehingga tarian ini tidak mengalami perkembangan dari segi gerakan, tata busana hingga musik iringan karena pada dasarnya tarian ini merupakan tarian sakral yang harus dilestarikan. Tari Rejang Sakral Lanang dipersembahkan atau ditarikan pada setiap pura (Kahyangan Desa) yang ada di Desa Mayong ketika Pujawali Rejang.

Hal senada disampaikan Jro Gede Nyoman Supastra

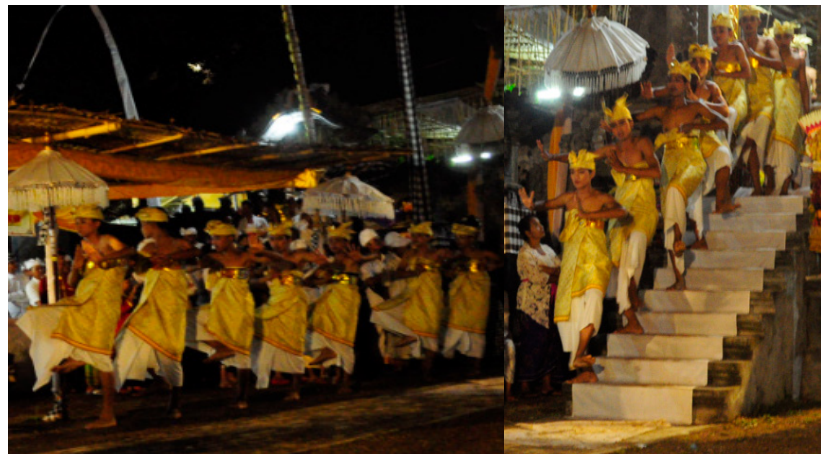

Gambar 3. Gerakan nengkleng ngawan dan nengkleng ngebot dalam Tari Rejang Sakral Lanang di Desa Mayong

(Dok. Kurnia, 2017)

(wawancara pada tanggal 03 Oktober 2017) yang mengatakan, Tari Rejang Sakral Lanang di Mayong merupakan simbol dari purusa (laki-laki) sehingga Tari Rejang Sakral Lanang ditarikan oleh laki-laki dan merupakan sebuah representasi dari perwujudan widyadara, yang diyakini masyarakat Mayong sebagai kesenangan dari Sesuhunan di Desa Mayong. Berdasarkan pendapat dari kedua informan dapat disimpulkan bahwa Tari Rejang Sakral Lanang di Desa Mayong memiliki unsur kesatuan atau keutuhan di dalamnya yang menjadikan tari tersebut memiliki estetika gerak. Keutuhan dalam hal ini dapat dilihat dari tidak adanya perubahan baik penambahan atau pengurangan terhadap gerak tarian tersebut, sehingga dalam tarian hanya terdiri dari empat gerakan saja.

"Keserasian adalah kesesuai, keselaras, keharmonisan, dan kesepadan" (Tim, 2011:2183). Walaupun gerakan dalam Tari Rejang Sakral Lanang di Desa Mayong hanya terdiri dari empat gerakan saja, tetapi tarian ini mengandung unsur keserasian di dalamnya. Hal tersebut dikarenakan struktur dalam tarian tersebut menggunakan struktur tunggal, sehingga terdapat penggulangan gerak dalam tarian tersebut. Berikut ilustrasi gerak-gerak pada Tari Rejang Sakral Lanang di Desa Mayong di bawah ini.

Nengkleng ngebot, agem ngawan, nengkleng ngebot, agem ngawan, nengkleng ngebot, nindak ngebot, nutup ngebot, nindak ngebot, nutup ngebot, nindak ngebot, nengkleng ngawan, agem ngebot, nengkleng ngawan, agem ngebot, nengkleng ngawan, nindak ngawan, nutup ngawan, nindak ngawan, nutup ngawan, nindak ngawan (gerakan tersebut diulangi kembali dari awal tarian hingga akhir akhir tarian tanpa perubahan irama musik iringan tari). "Pembagian ruang gerak Tari Bali selalu diwarnai adanya keseimbangan antara sisi kiri dan sisi kanan. Keseimbangan bisa terjadi secara simetris maupun asimetris misalnya agem ngawan dan agem ngebot" (Dibia, 2013:53). Gerak Tari Rejang Sakral Lanang di Desa Mayong mempergunakan konsep rwa bhinedha di dalamnya yang dapat dilihat dari adanya gerakan dari kanan dan dari kiri, ataupun gerakan dari atas dan gerakan dari bawah. Menurut Rai (2001:130132) "orang Bali, dimanapun berada dan apapun yang diperbuat, berdasarkan lontar Prakempa perbuatan yang 


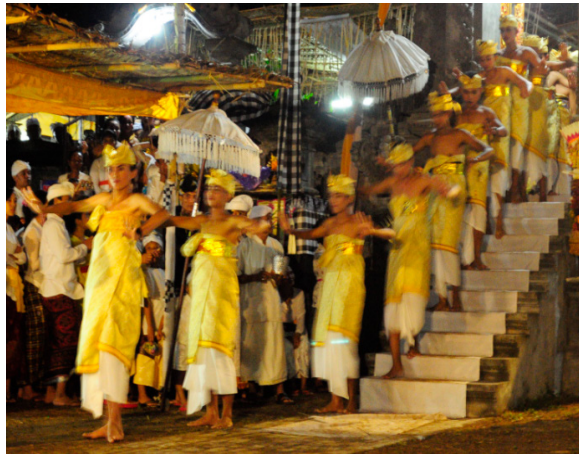

Gambar 4. Gerakan nutup ngebot dan nindak ngebot dalam Tari Rejang Sakral Lanang di Desa Mayong

(Dok. Kurnia, 2017)

dilakukan mengacu kepada konsep keseimbangan hidup yang terdiri dari sepuluh bagian (dimensi)". Salah satu dimensi tersebut adalah rwa bhinedha yang termasuk ke dalam keseimbangan hidup dua dimensi, yang memiliki arti percaya terhadap adanya dua kekuatan yang bertolak belakang seperti buruk dan baik, malam dan siang, perempuan dan laki, dan sebagainya. Rwa bhinedha dalam kesenian Bali merupakan konsep yang tidak bisa dilepaskan serta mendasar khususnya pada seniman, karya seni dan penonton.

Pola lantai di tempat pementasan pada Tari Rejang Sakral Lanang juga memberikan keserasian atau keseimbangan kepada penari Rejang Sakral Lanang di Desa Mayong. Ini dapat dibuktikan dengan gerakan yang dilakukan oleh penari menciptakan sebuah pola lantai lurus dan melengkung yang juga berkonsepkan rwa bhinedha (keseimbangan) di dalam tempat pementasan (panggung) yang berbentuk $k a$ langan yang juga terdiri dari sisi kanan dan sisi kiri, sehingga tercipta sebuah keserasian. Soedarsono (1975:04) dalam buku Komposisi Tari Elemen-elemen dasar (terjemahan buku Dance Composition the Basic Elements karangan La Meri) menyebutkan bahwa "tari sangat berkaitan dengan keharmonisan antara desain lantai dan desain atas". Gerak dalam Tari Rejang Saktal Lanang di Desa Mayong termasuk ke dalam desain atas dan pola lantai termasuk ke dalam desain lantai. Keserasian (keseimbangan) gerak yang terdapat di dalam Tari Rejang Saktal Lanang di Desa Mayong dipengaruhi juga dengan tata busana, tata rias, dan musik iringan. Berikut di bawah ini penjelasannya.

Keserasian antara gerak dan tata busana dapat dilihat dari warna yang terdapat di dalam pakaian adat madya sebagai tata busananya yang memberikan pengaruh kepada gerakan. "Warna merupakan salah satu perihal yang penting dalam memastikan tangapan orang. Warna merupakan sesuatu yang dilihat seseorang pertama. Setiap warna dapat memberikan identitas dan tanggapan tertentu, yang juga dipengaruhi pada pengalaman pengamatnya" (Nugroho, 2008:01). Warna dominan putih dan kuning yang terdapat di dalam tata busana pada Tari Rejang Sakral Lanang san-

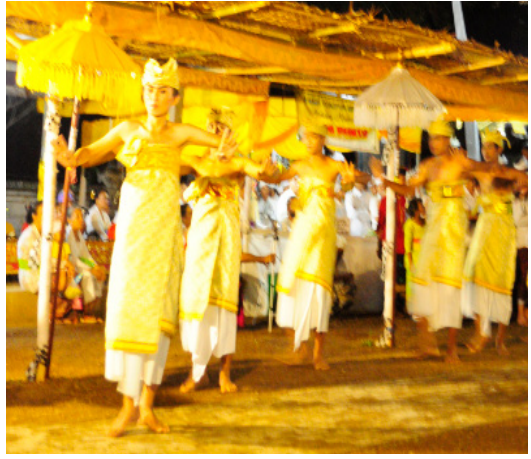

Gambar 5. Gerakan nindak ngawan dan nutup ngawan dalam Tari Rejang Sakral Lanang di Desa Mayong

(Dok. Kurnia, 2017)

gat mempengaruhi gerakan yang ada di dalam tarian tersebut, sebab warna dalam tata busana memberikan kesan keserasian terhadap gerak Tari Rejang Sakral Lanang. Putih dan kuning menurut orang Bali merupakan simbol dari dewa bermataangin di timur untuk Dewa Iswara (putih) dan di barat untuk Dewa Mahadewa (kuning) yang juga berkonsepkan rwa bhinedha di dalamnya.

Gerak dan tata rias memiliki keserasian yang dapat dilihat dari tata rias natural yang dipergunakan selain memberikan pengkarakteran kepada penari Rejang Sakral Lanang di dalam melakukan gerak tari, juga memberikan kesan keseimbangan di dalamnya. Ini dapat dibuktikan dengan tata rias yang ditampilkan di wajah penari ada di bagian wajah kanan dan wajah kiri yang sama atau simetris sehingga juga memiliki keseimbangan atau keserasian, sehingga gerak Tari Rejang Sakral Lanang di Desa Mayong adalah gerak tari putra halus yang didukung dengan tata riasnya.

Musik iringan tari dan gerak juga memiliki keserasian yang dapat dilihat dari adanya kekompakan (hubungan timbal balik) antara gerakan yang dilakukan oleh penari di atas panggung dengan nada-nada dari musik iringan tari yang dimainkan oleh penabuh di dalam pementasan Tari Rejang Sakral Lanang di Desa Mayong yang membuat masyarakat Mayong menjadi lango (terpesona), sebab masyarakat memandang bahwa tari dan musik iringan memiliki keserasian di dalamnya. Berdasarkan pemaparan di atas dapat disimpulkan bahwa gerak dalam Tari Rejang Sakral Lanang di Desa Mayong memiliki perimbangan atau keserasian di dalamnya yang didukung dengan tata busana, tata rias dan musik iringan tari.

"Kejelasan adalah terang, nyata, tidak ragu-ragu atau bimbang” (Tim, 2011:574). Kejelasan atau kecemerlangan dalam Tari Rejang Sakral Lanang di Desa Mayong dapat dilihat dari "identitas" dari tarian tersebut. Menurut wawancara dengan Jro Made Antara, (wawancara pada tanggal 27 Oktober 2017) dikatakan bahwa, gerakan Tari Rejang Sakral Lanang di Desa Mayong diwarisi secara vertikal dari penari senior dahulu ke penari junior sekarang, seh- 
ingga gerakan yang ditampilkan merupakan gerakan yang didapat dari penari terdahulu sehingga masyarakat Desa Mayong tidak berani merubahnya. Masyarakat hanya bisa memelihara dan tetap menjaga kelestariaan tarian tersebut. Pendapat dari Jro Made Antara diperkuat oleh pendapat dari Jro Gede Nyoman Supastra (wawancara pada tanggal 12 Februari 2018) yang mengatakan bahwa keempat gerakan yang ada di dalam Tari Rejang Sakral Lanang tidak boleh dikembangkan ataupun dirubah karena gerakan dalam tarian tersebut sudah diwariskan oleh generasi dahulu, sehingga Tari Rejang Sakral Lanang di Desa Mayong hanya terdiri dari empat gerakan saja yang dilakukan dari awal hingga akhir tarian. Berdasarkan kedua informasi tersebut dapat dikatakan bahwa Tari Rejang sakral Lanang di Desa Mayong memiliki kejelasan di dalamnya yang telah diwarisi dari dahulu hingga saat ini, sehingga memiliki identitas di dalamnya.

Identitas yang dimaksud adalah Tari Rejang Sakral Lanang di Desa Mayong merupakan salah satu tari wali yang hanya dipentaskan setiap 15 tahun sekali di Desa Mayong pada saat Pujawali Rejang yang ditarikan oleh penari lanang (laki-laki) yang bersih dan suci. Tarian ini memiliki unsur kejelasan yang dapat dilihat seperti tata busana, gerak tari, musik iringan tari, tata rias, serta tempat pementasan. Gerak tarian ini memiliki unsur kejelasan yang dapat dilihat dan memiliki unsur kejelasan yang dapat didengar seperti bunyi gamelan yang mengiringi Tari Rejang Sakral Lanang di Desa Mayong. Unsur kejelasan pada gerak Tari Rejang Sakral Lanang di Desa Mayong dapat dilihat dari gerakan yang terdapat di dalam tarian tersebut hanya terdiri empat gerakan saja dan membuatnya berbeda dengan Tari Rejang pada umumnya. Gerakan yang dilakukan juga didukung oleh penari yang berjumlah minimal 15 orang penari dengan menggunakan pakaian adat madya sebagai tata busana dan didukung dengan tata rias natural sebagai tata riasnya. Tempat pementasan Tari Rejang Sakral Lanang menggunakan panggung jenis kalangan dan dapat dilihat kejelasannya. Berikut di bawah ini ilustrasi gerak-gerak pada Tari Rejang Sakral Lanang di Desa Mayong yang memiliki unsur kejelasan yang didukung dengan tata busana dan tata rias.

\section{SIMPULAN}

Gerak yang terdapat pada Tari Rejang Sakral Lanang hanya terdiri dari empat gerakan antara lain: agem, nengkleng, nindak dan nutup yang dilakukan dari awal tarian hingga akhir tarian dan struktur dalam tari ini menggunakan struktur tunggal sehingga memiliki kesatuan utuh. Gerakan Tari Rejang Sakral Lanang di Desa Mayong sangat sederhana yang diwarisi secara vertikal dari penari senior dahulu ke penari junior sekarang. Gerakan pada tarian ini memiliki nilai estetika di dalamnya karena sesuai dengan pendapat estetika dari Thomas Aquinas yang berpendapat bahwa keindahan meliputi tiga persyaratan yaitu keutuhan atau kesempurnaan, perimbangan atau keserasian dan kecemerlangan atau kejelasan. Kesatuan dapat dilihat dari gerakan dalam tarian tersebut yang didukung dengan elemen-elemen lain dalam tari meliputi tata busana, tata rias, dan musik iringan sesuai dengan karakter tari, sehingga menjadi utuh (saling terkait) dan dapat mendukung keutuhan gerak dalam Tari Rejang Sakral Lanang di Desa Mayong. Keserasian atau perimbangan dalam Tari Rejang Sakral Lanang di Desa Mayong dapat dilihat dari keempat gerakan yang terdapat dalam Tari Rejang Sakral Lanang di Desa Mayong dilakukan secara berulang-ulang dari awal hingga akhir tarian ketika pementasan, sehingga terdapat pengulangan gerak dari kanan ke kiri atau sebaliknya. Keserasian antara gerak dengan musik iringan tari dapat dilihat dari kekompakan (hubungan timbal balik) antara gerakan yang dilakukan oleh penari di atas panggung dengan nada-nada dari musik iringan tari dan juga adanya keharmonisan antara desain lantai (pola lantai) dan desain atas (gerakan). Unsur kejelasan pada gerak Tari Rejang Sakral Lanang di Desa Mayong dapat dilihat dari gerakan yang terdapat di dalam tarian tersebut hanya terdiri empat gerakan saja dan membuatnya berbeda dengan Tari Rejang pada umumnya. Gerakan yang dilakukan juga didukung oleh penari, tata busana, tata rias, dan tempat pertunjukan yang juga dapat dilihat kejelasannya. Berdasarkan pendapat Aquinas dapat simpulkan bahwa gerak pada Tari Rejang Sakral Lanang di Desa Mayong memiliki estetika di dalamnya.

\section{UCAPAN TERIMA KASIH}

Ucapan ini peneliti lantunkan kehadapan Sumber segala Sumber dengan anugerah-Nya, artikel dengan judul "Estetika Gerak Tari Rejang Sakral Lanang Di Desa Mayong, Kecamatan Seririt, Kabupaten Buleleng" dapat diselesaikan tepat pada waktunya. Peneliti sepenuhnya sadar bahwa, atas dorongan bantuan dari pihak-pihak terkait, penelitian Estetika Gerak Tari Rejang Sakral Lanang Di Desa Mayong, Kecamatan Seririt, Kabupaten Buleleng dapat dengan baik terwujud, sehingga peneliti ingin mempersembahkan rasa terima kasih kepada:

Ucapan terima kasih juga peneliti haturkan pada Ristekdikti yang telah memberikan bantuan dana untuk penelitian Tesis Magister yang berjudul "Analisis Proses Perwujudan Wayang Tantri dan Bentuk Seni Rejang Sakral Sebagai Sebuah Pertunjukan" melalui kontrak Nomor: 139/IT.5.3/PG/2019.

Selanjutnya kepada I Nyoman Sudira, SST.,M.Pd., Ni Ketut Sari, S.Sos dan I Wayan Adiyasa S.Pd.,M.Eng selaku orang tua dan kakak peneliti yang telah memberikan dorongan materi dan non materi terhadap penelitian ini. Jro Gede Nyoman Supastra, Jro Made Antara dan Putu Ardian Eka Putra yang menjadi informasi di dalam penelitian ini dan telah memberikan banyak informasi mengenai gerak Tari Rejang Sakral Lanang di Desa Mayong. 
Akhir kata peneliti berharap bahwa penelitian ini bisa berguna bagi pembaca. Oleh sebab itu, peneliti memerlukan saran dan kritik yang dapat menyempurnakan penelitian ini dikemudian hari.

\section{DAFTAR RUJUKAN}

Agung, A. A. A. K. (2004). Busana Adat Bali. Denpasar: Pustaka Bali Post.

Bandem, I. M. (1983). Ensiklopedi Tari Bali. Denpasar: Sekolah Tinggi Seni Indonesia (STSI) Denpasar.

Bandem, I. M. (2005). Tari Bali Sebuah Simbol Masyarakat Bali. Seni, 1(1), 9-21.

Bungin, Burhan. (2015). Penelitian Kualitatif: Komunikasi, Ekonomi, Kebijakan Publik, Dan Ilmu Sosial Lainya-Edisi Kedua. Jakarta: Prenada Media Group.

Cerita, I. N. (2009). Analisis Tari dan Gerak. Denpasar: Institut Seni Indonesia Denpasar.

Dibia, I. W. (1999). Selayang Pandang Seni Pertunjukan Bali. Bandung: Masyarakat Seni Pertunjukan Indonesia.

Dibia, I. W. (2013). Puspasari Seni Tari Bali. Denpasar: UPT. ISI Denpasar.

Gie, T. L. (2004). Filsafat Keindahan. Yogyakarta: Pusat Belajar Ilmu Berguna (PUBIB).

Hawkins, A. M. (2003). Mencipta Lewat Tari. Terj. Y. Sumandiyo Hadi. Yogyakarta: Manthili.

Koentjaraningrat. (1995). Manusia dan Kebudayaan di Indonesia. Jakarta: Djambatan.

Kussudiardjo, B. (1981). Tentang Tari. Yogyakarta: C.V:Nur Cahaya.

Moleong, L. (2012). Metodologi Penelitian Kualitatif Edisi Revisi. Bandung: PT. Remaja Rosdakarya.

Nugroho, E. (2008). Pengenalan Teori Warna. Yogyakarta: C.V Andi Offset.

Rai, Wayan. (2001). Gong Antropologi Pemikiran. Denpasar: Bali Mangsi.

Ratna, Nyoman Kutha. (2010). Metodologi Penelitian Kajian Budaya Dan Ilmu Sosial Humaniora Pada Umumnya. Yogyakarta: Pustaka Belajar.

Sarwono, Jonathan. (2006). Metode Penelitian Kuantitatif \& Kualitatif. Yogyakarta: Graha Ilmu,
Soedarsono. (1975). Komposisi Tari Elemen-elemen Dasar. Yogyakarta: Akademi Seni Tari Indonesia.

Soedarsono. (1977). Tari-tarian Indonesia I. Jakarta: Proyek Pengembangan Media Kebudayaan. Direktorat Jendral. Departemen Pendidikan Dan Kebudayaan.

Tim Redaksi. (2011). Kamus Besar Bahasa Indonesia Pusat Bahasa Edisi Keempat. Jakarta: PT Gramedia Pustaka Utama.

Widjaja, N. L. . S. (1997). Busana Tari: Sebuah Refleksi Dan Tantangan. Mudra Jurnal Seni Dan Budaya, V(No.5), 80-89.

Yudabakti, I. M. dan I. W. W. (2007). Filsafat Seni Sakral Dalam Kebudayaan Bali. Surabaya: Paramita. 